\title{
ARUBOLANA PARVIOCULATA N. SP. (ISOPODA, CIROLANIDAE)
}

\author{
FROM THE INTERSTITIAL OF AN INTERMITTENT RIVER IN JAMAICA, \\ WITH NOTES ON $A$. IMULA BOTOSANEANU \& STOCK AND $A$. ARUBOIDES \\ (BOWMAN \& ILIFFE)
}

\author{
by \\ JOS NOTENBOOM \\ Institute of Taxonomic Zoology (Zoölogisch Museum), University of Amsterdam, \\ P.O.Box 20125, 1000 HC Amsterdam, The Netherlands
}

\section{SUMMARY}

Arubolana parvioculata, a new stygobiont species of cirolanid isopod crustaceans, is described from an interstitial habitat near the mouth of an intermittent river, the Rio Secco, Discovery Bay, Jamaica. This is the first subterranean cirolanid from Jamaica. Alltogether, 6 genera of stygobiont cirolanids, with 9 species, are known from 7 islands in the West Indies. The new species has a small and elongate body, which is typical of inhabitants of interstitia. It is also euryhaline.

An additional description is given of Arubolana imula Botosaneanu \& Stock, 1979, type-species of the genus, based on new specimens from the type-locality. Bermudalana aruboides Bowman Iliffe, 1983, from caves on the oceanic island Bermuda, is referred to the genus Arubolana. The morphological and ecological differences between the three Arubolana species are pointed out. Some of these differences are usually considered characteristic of distinction on generic level; therefore the three species possibly have to be recognized as members of different subgenera, but on account of our limited knowledge this decision has not been made.

It is presumed that the Arubolana species originated from a Metacirolana type of marine ancestor. A general evolutionary scenario for Arubolana is difficult to construct. $A$. imula is considered a regression element, but $A$. aruboides and $A$. parvioculata can be either regression and/or dispersal elements.

\section{RÉSUMÉ}

Une espèce nouvelle d'Isopodes Cirolanides, Arubolana parvioculata, est décrite. Ce premier Cirolanide hypogé de la Jamaïque a été découvert dans un habitat interstitiel, près de l'embouchure d'une rivière intermittente, le Rio Secco

* Report 38 is published in the same issue of this journal.
(Discovery Bay). Jusqu'à présent, 6 genres de Cirolanides stygobiontes, avec 9 espèces, sont connus de 7 îles des Indes Occidentales. La nouvelle espèce est de petite taille et allongée, caractères typiques des habitants des interstices. C'est une espèce euryhaline.

Une description supplémentaire est donnée pour Arubolana imula Botosaneanu \& Stock, 1979 (espèce-type du genre); celle-ci est réalisée sur des exemplaires supplémentaires capturés dans la terra typica. Bermudalana aruboides Bowman \& Iliffe, 1983, de grottes de Bermuda, est considerée comme appartenant à Arubolana. On souligne les différences morphologiques et écologiques entre les trois espèces d'Arubolana; certaines de ces différences sont habituellement considérées comme permettant une distinction au niveau générique. Il est donc possible que les trois espèces devront être considérées comme appartenant à des sous-genres distincts, mais, compte tenu de l'imparfaite connaissance que nous avons sur le groupe, cette décision n'a pas été prise.

On peut supposer que les Arubolana sont dérivées d'un ancêtre marin du type Metacirolana, mais il est difficile d'établir un scénario des événements. On considère $A$. imula comme élément de regression, tandis que $A$. aruboides et $A$. parvioculata peuvent être aussi bien des éléments de regression et/ou de dispersion.

\section{INTRODUCTION}

In the series of publications dealing with the stygobiont fauna collected during the Amsterdam Expeditions to the West Indian Islands, this is the third article concerning cirolanid isopods. The previous publications in this series were by Botosaneanu \& Stock (1979) and Notenboom (1981). In the present paper a new species from Jamaica is described from the 
water table in river sediments near the coast. Furthermore, Arubolana imula Botosaneanu \& Stock, 1979, the original description of which was based on one juvenile male only, has been studied again, now based on more specimens from the type-locality, collected during the 1980 expedition. Bermudalana aruboides Bowman \& Iliffe, 1983, is transferred to the genus Arubolana. The affinities, position within the family, and the zoogeography of the Arubolana species are discussed.

Until five years ago, the only hypogean cirolanids known from the West Indies were the Cuban species Haptolana trichostoma Bowman, 1966, and Troglocirolana** cubensis (Hay, 1903). During the past few years, however, different biologists have contributed to this fauna, from several islands: Botosaneanu \& Stock, 1979 (Arubolana imula from Aruba), Carpenter, 1981 (Bahalana geracei from San Salvador Island), Notenboom, 1981 (Bahalana cardiopus from Mayaguana, and Haitilana** radicicola and $H$. acanthura from Haiti), and finally Bowman \& Franz, 1982 (Anopsilana** crenata from Grand Cayman). The result is that at the moment 6 genera with 9 species are known from 7 islands (see map 1).

Most of these cirolanids are inhabitants of cave waters; however, the two species of Haitilana are known from a karstic spring and a well, respectively, and a new species discussed in this paper was discovered in another type of groundwater habitat, the interstitial of a temporary river.

Some remarks on the morphology of stygobiont cirolanids

While studying stygobiont cirolanids, I encountered some obscurities in the use by different authors of morphological terms. In this section the terminology used for some parts of the cirolanid body will be discussed.

** Bruce (in press) regards Troglocirolana and Haitilana as synonymous with Anopsilana Paulian \& Delamare Deboutteville, 1956, considered a paraphyletic genus.
The peduncle of the first antenna in cirolanids is composed of three articles of which article one and two can be partly or totally fused. In the distal part of the third article a differentiated zone can be recognized, separated from the third article (figs. 5-6, 33-34). This zone has often been illustrated by isopodologists (Bowman, 1966; Monod, 1930; Racovitza, 1912; Rioja, 1956) but has rarely been described. Theoretically there are three possibilities: this zone is part of the peduncle, or a flagellum article, or an articulation zone. In both Arubolana imula and $A$. parvioculata, setae are implanted on this apical zone, which suggests that it is not just an articulation between flagellum and peduncle. Although observation is very difficult either with light microscopy or with scanning electron microscopy, it is my impression that the limit between peduncular article 3 and this zone is either only partially or not at all chitinized, and that the zone itself is rather membranous. This suggests that it belongs to the peduncle. Botosaneanu \& Stock (1982) mentioned a similar situation in the genus Cyathura (Anthuridea), and they reached the same conclusion: they considered this zone as a differentiated part of the last peduncular article, with possibly a prevailing sensorial function. Bruce (in press) considers this zone as being a "fourth small fused terminal article", and in my opinion it seems probable that it originated from a fourth peduncular article.

Another problem in the literature on cirolanid isopods is the confusion in the terminology used by some authors for the mandibular parts (figs. 9-10, 35 and 37). In my opinion these parts have to be named as follows: the strongly sclerotized, dark coloured, tridenticulated median margin is the masticatory blade or pars incisiva; laterally is the triarticulated palp, with setation on the second and third article; between the palp and the masticatory blade, small unarmed lobes are found, which represent the molar process or pars molaris; dorsomedially is a denticulated, triangular, mobile (articulate) process, the lacinia mobilis; between lacinia mobilis and the masticatory blade is a lobe, strongly armed with 
spines, the incisor; sometimes the masticatory blade has an accessory spine laterally. Carpenter (1981), on the contrary, named the incisor, lacinia mobilis, and the lacinia mobilis, molar; Bruce (1981) named the masticatory blade, incisor, and the incisor, molar process; Bowman \& Iliffe (1983) named the masticatory blade, incisor, the lacinia mobilis, molar, and the incisor, lacinia.

With respect to the pereiopods, there is a problem in deciding whether a pereiopod is prehensile or ambulatory. Bruce (pers. comm.) adopted the following criterion: when the dactylus is longer than the greatest length of the propodus, the pereiopod is considered prehensile; when the dactylus is shorter, it is considered ambulatory. In my opinion this is too simple a view. The best criteria are observations on living specimens, but these are usually not available. According to Bruce's criterion, the first and second pereiopods of Arubolana should be called ambulatory. In my opinion the first and second pereiopods are clearly prehensile in this taxon, while the propodus is much wider than the dactylus, and carpus and merus are wider than long. Furthermore, the first and second pereiopods are relatively short and strongly built, and are, in preserved specimens, pressed against the body, while the other pereiopods are not (observations based on $\boldsymbol{A}$. imula and $A$. parvioculata).

My last remark concerns the chaetotaxy. There is no uniformly defined and used system for the nomenclature of crustacean setae. However, setae play an important role in crustacean taxonomy. Broodbakker \& Danielopol (1982) described a model for the chaetotaxy of ostracods. They adopted some general terms from decapod literature, which are also useful for the description of cirolanid setae: simple set ae have a smooth distal shaft; serrate setae have spiky or toothlike setules; plumed setae possess flexible setules (hairy appearance), they can be subdivided into plumose setae when the setules are arranged in one or two rows along the largest distal part and pappose setae when the setules arise from all sides of the distal part.

\section{TAXONOMIC PART}

\section{Arubolana Botosaneanu \& Stock, 1979}

Diagnosis. - Depigmented Cirolanidae (except for brown masticatory blades), blind or with small eyes. Body not able to roll into a ball; pleon with 5 free segments, lateral margin of segment 5 free or overlapped by segment 4 . Clypeus much wider than high, anterior margin of frontal lamina broad. Antenna 1 not longer than the peduncle of antenna 2; peduncle 3-articulated; flagellum 5-articulated, with aesthetascs. Peduncle of antenna 2 5-articulated, flagellum with relatively few articles. Mandible and first maxilla normal; second maxilla showing loss of articles. Maxillipedal palp 4-articulated (articles 2 and 3 fused); endite with one or two pappose setae, possibly with coupling element. Pereiopods 1 and 2 prehensile, pereiopod 3 ambulatory or intermediate in shape between ambulatory and clearly prehensile, pereiopods 4 to 7 ambulatory. Rami of pleopods 1 and 2 undivided; exopodites of third to fifth pleopods 2-segmented. Appendix masculina implanted subterminally on the median margin of endopodite, straight in adult males, possibly with apical spiniform elements. Uropodal protopodite with median margin produced. Telson trapezoidal, scarcely armed.

Type-species. - Arubolana imula Botosaneanu \& Stock, 1979. An additional description of it is given in the sequel, after the description of the new species Arubolana parvioculata. Some remarks on $A$. aruboides (Bowman \& Iliffe, 1983) are made as well.

Arubolana parvioculata n. sp.

(Figs. 1-27, 47-48)

Material examined. - Amsterdam Expeditions to the West Indian Islands, 1982. Jamaica: Interstitial water in the sediments near the mouth of the Rio Secco in the dry riverbed, Discovery Bay $\left(18^{\circ} 27^{\prime} 21^{\prime \prime N} 77^{\circ} 24^{\prime} 34^{\prime \prime} \mathrm{W}\right)$; coll. J. H. Stock: sta. 82/134 (28 March 1982, about $15 \mathrm{~m}$ from the sea, Zoölogisch Museum Amsterdam coll. no. ZMA Is. $105.247 \mathrm{a} \& \mathrm{~b}, 3 \sigma^{\circ} \sigma^{\circ}$ and 1 Q ); sta. 82/136 (28 March 1982 , about $35 \mathrm{~m}$ from the sea, ZMA coll. no. Is. 105.248, 
$2 \sigma^{\circ} \circ$ and 2 \% $९$ ); sta. 82/138 (29 March 1982, between the preceding stations, ZMA coll. no. Is. 205.249, $4 \sigma^{\circ} \sigma^{\circ}$ and $7 \&$, one of which damaged). The holotype is a 2.8 $\mathrm{mm}$ long male from sta. $82 / 134$, the other specimens are paratypes.

Description. - Body (fig. 1) 3.2-3.3 times longer than wide. Males range to a maximum length.. of $2.8 \mathrm{~mm}$, females to $2.9 \mathrm{~mm}$. Pereionite 1 slightly longer than the others, pereionites 2 to 4 as well as 5 to 7 of about the same size, last three pereionites longer than the three preceding ones (fig. 1); posterior corner of coxal plates 2 and 3 rounded, plate 4 rectangular and plates 5 to 7 posteriorly pointed (fig. 2). Penes prominent on sternite 7 (fig. 12). Pleonites 1 to 4 almost as wide as pereionite 7, pleonite 1 partly covered dorsally by pereionite 7 (fig. 1); epimera 1 to 4 posteroventrally pointed, epimera 5 partly covered by epimera 4 (fig. 2). Telson trapezoidal, narrow at posterior margin, which is slightly concave, crenate and armed with a few simple setae (fig. 21).

Antenna 1 short, reaching halfway to last peduncular article of antenna 2 and to the posterior margin of the head; peduncle 3-articulated, articles 1 and 2 of about the same length, article 1 distally with 3 or 4 setae, article 2 armed with 4 to 6 setae medially and 2 setae laterally, article 3 about twice as long as article 2 , armed distolaterally with 3 or 5 setae, apical zone with 3 or 4 plumose setae (fig. 5); flagellum 5-articulated, article 1 almost three times as long as the other articles together, long aesthetascs on articles 1 to 4 , article 5 with 3 or 4 setae on the tip (fig. 6).

Antenna 2 reaching to the anterior margin of pereionite 4; peduncle 5-articulated, articles 1 and 2 partly fused, article 5 the longest, as long as articles 3 and 4 together, article 1 unarmed, article 2 with 1 to 4 setae, article 3 with 2 to 4 setae, article 4 with several simple setae and 1 or 2 plumose setae, article 5 strongly armed, distally with several plumose setae; flagellum 6to 8-articulated, articles armed with several setae (fig. 4).

Frontal lamina freely projecting, anterior and posterior margin about of equal size, abutting on the clypeus; clypeus triangular, much wider than high, with freely projecting, rounded apex (figs. 3 and 47-48).

Mandibles with asymmetrical masticatory blades, right mandible with 3 large teeth and 1 small median tooth, left mandible with 3 flat teeth; lacinia mobilis longer than high with 14 or 15 small spines; incisor with about 8 spines (one naked, the remaining ones with small spikes); palp slender, 3-articulated, a distal group of 5 to 7 setae on segment 2, segment 3 distally with 3 to 5 setae, tip with 1 or 2 longer setae (figs. 9-10).

Maxilla 1: gnathal surface of exopodite with 10 strongly sclerotized setae, one naked, two with several spikes, and the remaining ones with 1 or 2 spikes; endite armed with 3 long, pappose setae and two simple setae (fig. 7).

Maxilla 2 strongly reduced, consisting of two fused segments, apex armed with 3 long setae (all pappose) and 2 or 3 simple setae (fig. 8).

Maxillipedal endopodite 4-segmented, segment 1 squarish with one seta, segment 2 largest with $1+4$ setae, segment 3 squarish with $1+3$ setae, segment 4 the smallest, armed with 7 setae ( 2 plumose); endite with only 1 or 2 pappose setae (fig. 11).

Pereiopod 1 prehensile, basis and ischium both with one seta, merus distoposteriorly with a process, a spine and a seta, carpus with a spine and a seta, propodus posteriorly with 2 spines and 4 setae, dactylus with 4 setules, with secondary unguis and little spine (fig. 13).

Pereiopod 2 prehensile, basis and ischium both with one seta, posterior margin of merus with lateral group of a spine and a seta, distally with a process and a group of setae, distal carpal process with a group of setae, propodus posteriorly with two processes and two groups of spines and setae, dactylus with 3 setules, apex with secondary unguis and two setules (fig. 14).

Pereiopods 3 to 7 ambulatory, 3-6 increasing in length, 7 shorter than 6 , little difference between pereiopods 2 and 3 (figs. 15-19).

Pleopod 1 smaller than pleopod 2, ovate exopodite and subrectangular endopodite, both rami subequal in length and with plumose setae (fig. 22). 

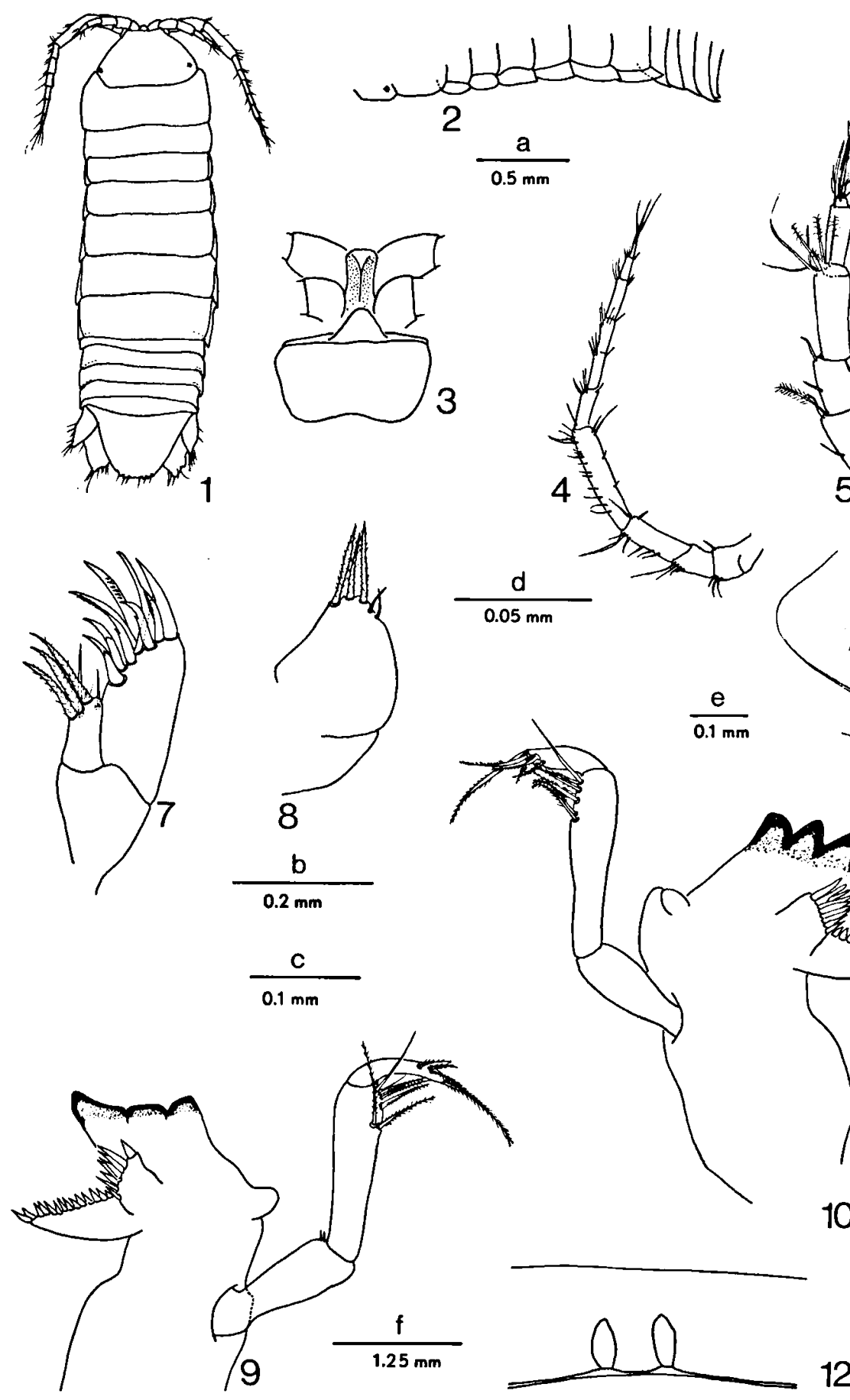

12

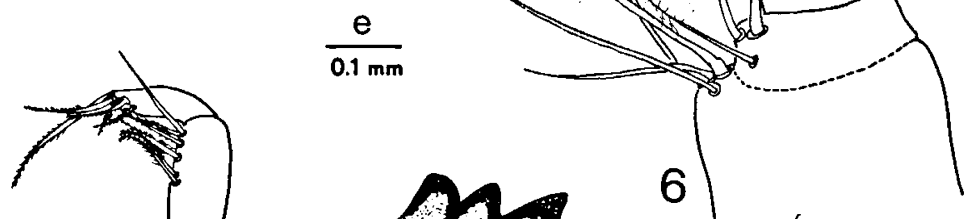

Figs. 1-12. Arubolana parvioculata n. sp., male: 1, entire animal (scale a); 2, pereionites laterally (a); 3, anteroclypeal region (b); 4 , antenna 2, right (b); 5 , antenna 1, left (e); 6, detail of flagellum of antenna 1, left (d); 7, maxilla 1, left (c); 8, maxilla 2, left (c); 9, mandible, left (c); 10, mandible, right (c); 11, maxilliped, right (c); 12, penes on sternite 7 (f). 


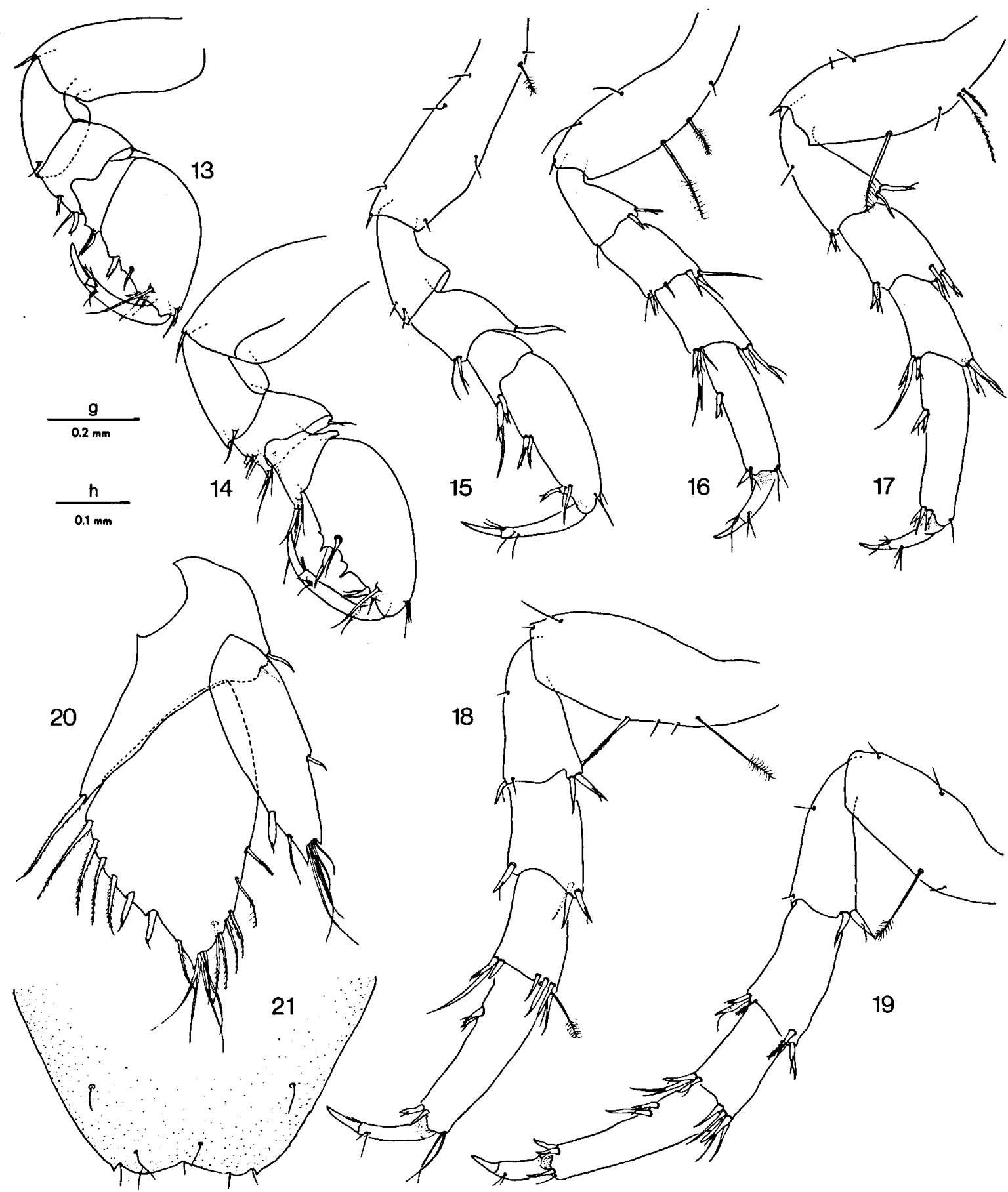

Figs. 13-21. Arubolana parvioculata n. sp., male: 13, pereiopod 1, left (scale g); 14, pereiopod 2, left (g); 15, pereiopod 3, left $(h) ; 16$, pereiopod 4, left $(h) ; 17$, pereiopod 5, left $(h) ; 18$, pereiopod 6, left $(h) ; 19$, pereiopod 7, left (h); 20, uropod, left $(\mathrm{h}) ; 21$, telson $(\mathrm{g})$. 


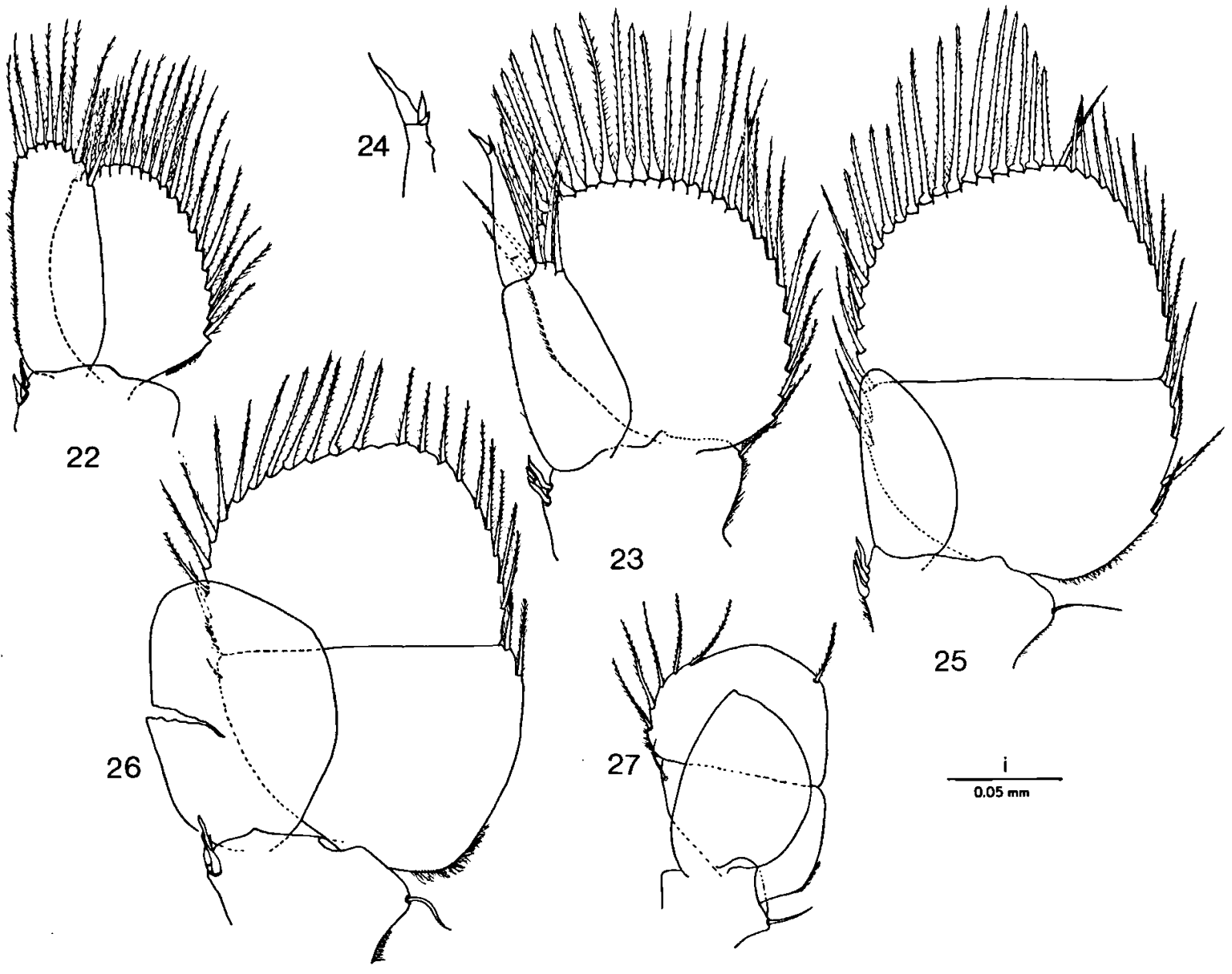

Figs. 22-27. Arubolana parvioculata n. sp., male: 22, pleopod 1, left (scale h); 23, pleopod 2, left (h); 24, detail of apex of appendix masculina (i); 25, pleopod 3, left (h); 26, pleopod 4, left (h); 27, pleopod 5, right (h).

Pleopod 2 in the male with very broadly rounded exopodite, armed with plumose setae, a group of setae with a blunt tip and broader base on mediodistal margin; endopodite smaller than exopodite, apex with 3 plumose setae; appendix masculina terminal, slightly shorter than endopodite, apex with 3 spiniform elements, one of which being longer (figs. 23-24).

Pleopod 2 in the female basically similar to that in the male, with several plumose setae on the endopodite.

Pleopod 3: large 2-segmented exopodite, distal segment with plumose setae (mediodistal margin with a group of setae with blunt tip and broader base), basal segment with several plumose setae; endopodite very small, hardly longer than basal segment of exopodite, unarmed and membranous (fig. 25).

Pleopod 4: large 2-segmented exopodite, distal segment with plumose setae (a small mediodistal group of setae of the blunt-tip type), basal segment with 2 plumose setae and a simple seta; endopodite small, reaching to the middle of the distal exopodal segment, unarmed and membranous (fig. 26).

Pleopod 5: small 2-segmented exopodite, distal segment scarcely armed with plumose setae, basal segment with one simple seta; endopodite smaller than exopodite, unarmed and membranous (fig. 27).

Uropod: protopodite wedge-shaped, mediodistally one plumose seta, laterodistally two simple setae; endopodite longer and wider than 
exopodite, on the apex a group of naked setae, and medially 5 plumose setae and 2 spines; exopodite oblong and narrow, armed on tip with a group of naked setae, lateral and median margins each with a spine (fig. 20).

Etymology. - The specific name is composed of the Latin words parvus $=$ small and oculus $=$ eye, and alludes to the small eyes of the animal.

Habitat. - Arubolana parvioculata n. sp. was caught by means of filtering water seeping into dug holes reaching the level of the water table (Karaman-Chappuis method) in the dry bed of the Rio Secco, Discovery Bay, Jamaica.

The sediments consisted of boulders, coarse gravel and coarse sand. The temperature of the water in the holes was about $26^{\circ} \mathrm{C}$. The hole closest to the sea $(15 \mathrm{~m})$ contained water with a chlorinity of $26580 \mathrm{mg} / \mathrm{l}$, and could be classified as seawater. The water in the two other holes, at $35 \mathrm{~m}$ and about $25 \mathrm{~m}$ from the sea, had chloride contents of 4848 and $5328 \mathrm{mg} / \mathrm{l}$, respectively, and could be classified as mixohaline water. This points to a large salt tolerance (euryhalinity) of $A$. parvioculata.

The fauna found together with the cirolanids can be considered a mixture of aquatic (groundwater) fauna and terrestrial (soil) fauna, certainly caused by disturbance of the substrate during the digging of the holes. In addition to the cirolanids, other aquatic animals were blind amphipods (Metaniphargus), isopods (Microcerberus), ostracods, polychaetes, and oligochaetes; soil fauna elements were terrestrial isopods, Collembola, pseudoscorpions, and myriapods. In general, only few individuals of this accompanying fauna were found.

Two other holes were dug at the same locality, but closer to the sea (about $2 \mathrm{~m}$ ). These stations contained neither cirolanids nor blind amphipods, but Microcerberus and polychaetes were present.

Arubolana imula Botosaneanu \& Stock, 1979 (Figs. 28-46)

Material examined. - Amsterdam Expeditions to the West Indian Islands, sta. 78/290, Aruba: Mangel
Cora Tunnel (Lago Colony), approximate position $12^{\circ} 25^{\prime} 13^{\prime \prime} \mathrm{N} 69^{\circ} 52^{\prime} 10^{\prime \prime} \mathrm{W}, 16$ May 1978 , ZMA coll. no. Is. $100.648 \mathrm{a} \& \mathrm{~b}$, one juvenile male $(2.9 \mathrm{~mm})$, holotype (coll. J. H. Stock and S. Weinberg). Sta. 80/17, same locality as sta. 78/290, 24 May 1980, ZMA coll. no. Is. $105.250,: 14$ females and 9 males, topotypes (coll. L. Botosaneanu and $\mathrm{J}$. Notenboom).

Additional description. - Body (fig. 28) rather wide, 2.2-2.4 times as long as wide. Maximum length of both males and females $6.25 \mathrm{~mm}$. Coxal plates on pereionites 2 to 7 posteroventrally pointed (fig. 29); pereionite 1 longer than the others; pereionite 3 partly covered by pereionite 2; pereionites 4 to 7 of about the same size (fig. 28). Pleonite 1 partly covered by pereionite 7; pleonites 2 to 4 almost as wide as pereionite 7 , epimera triangular. Penes on sternite 7 prominent (fig. 38). Telson trapezoidal, longer than wide, narrower at the posterior margin which is slightly concave and armed with a few simple setae (fig. 28).

Antenna 1 short, hardly longer than the posterior margin of the head; peduncle 3-articulated, articles 1 and 2 short, article 3 at least as long as 1 and 2 together (fig. 33); flagellum 5-articulated, article 1 about 3 times as long as the other articles together, articles 1 to 4 each with one elongate aesthetasc reaching beyond the tip of the flagellum, article 5 with a few long setae (fig. 34).

Antenna 2: peduncle 5-articulated, articles 1 and 2 partly fused; article 5 of about the same length as 3 and 4 together (fig. 43); flagellum 8-articulated (fig. 44).

Frontal lamina broad, rectangular, anteriorly fused with the rostrum, posteriorly not abutting on the clypeus. Clypeus about 7 times as wide as high, apex not freely projecting. Labrum and clypeus in the same plane (figs. 30 and 45-46).

Mandibular masticatory blades asymmetrical, left mandible occasionally with accessory spine; lacinia mobilis triangular, armed with 13-14 spines; incisor armed with 9-10 spines; palp article 2 with a distal group of about 8 setae, article 3 distally with 6-7 setae and 2 longer terminal setae (figs. 35, 37).

Maxilla 1: endite armed with 3 pappose setae 

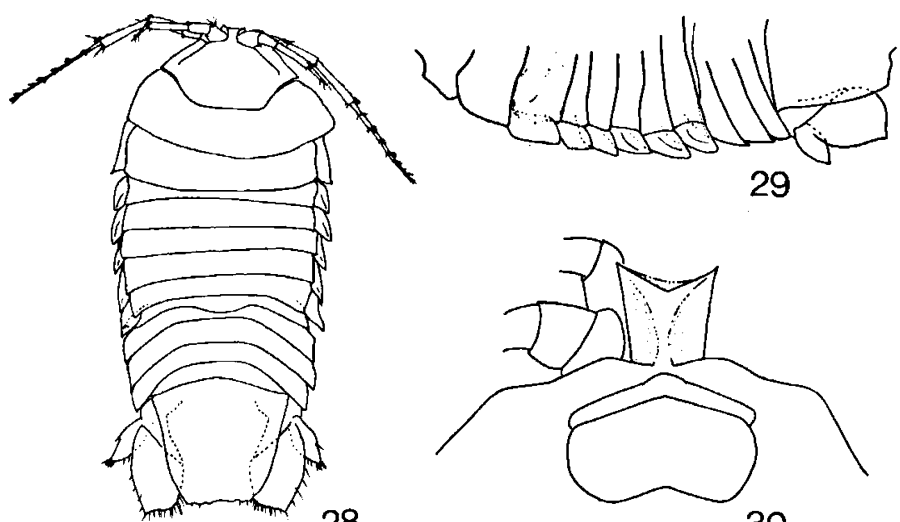

29

28
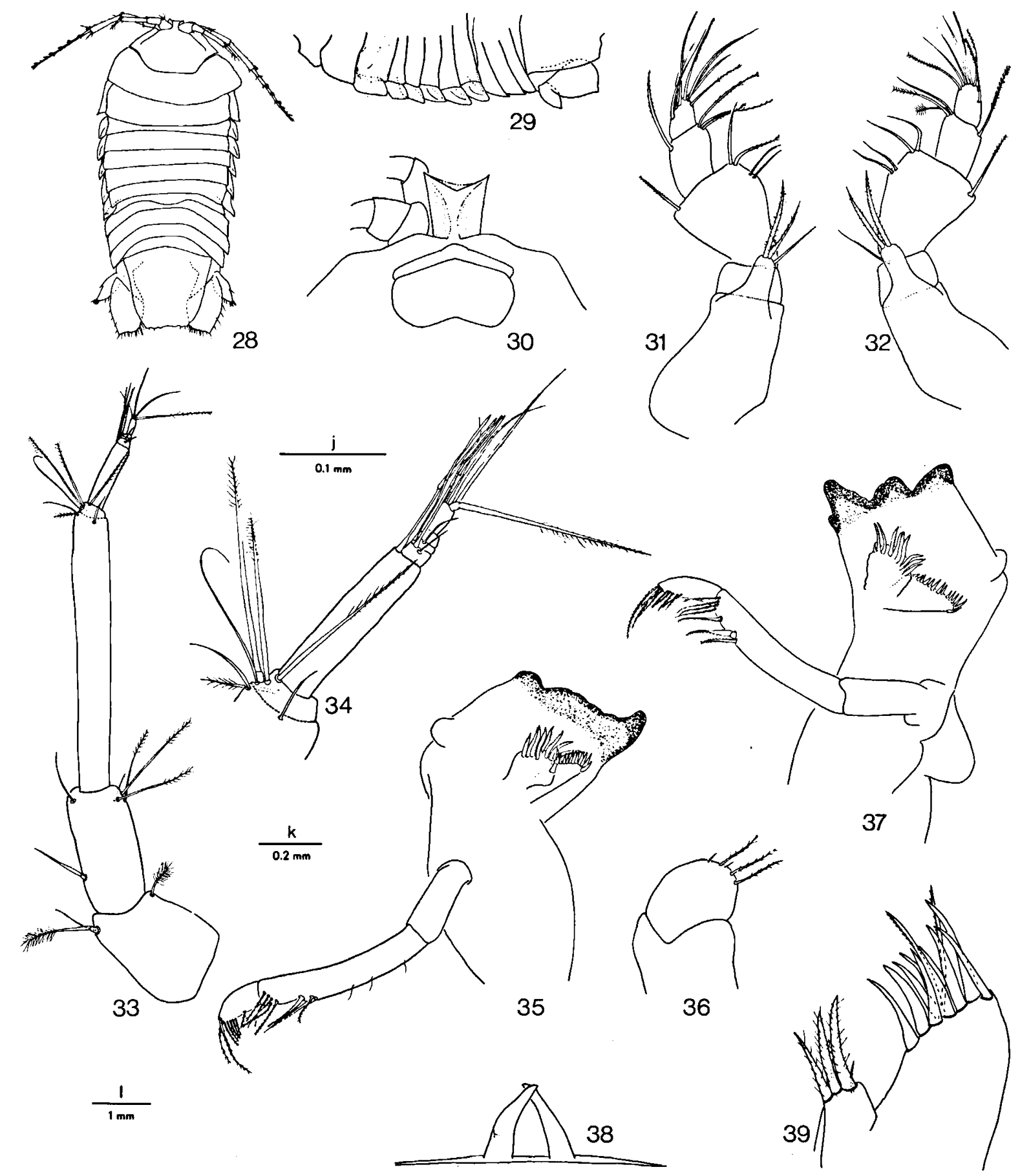

Figs. 28-39. Arubolana imula Botosaneanu Stock, 1979, topotypes: 28, entire animal, $९$ (scale l); 29, pereionites, lateral, ९ (1); 30, anteroclypeal region, $\sigma^{\circ}(\mathrm{k}) ; 31$, maxilliped, left, $\sigma^{\circ}(\mathrm{g}) ; 32$, maxilliped, right, $\sigma^{\circ}(\mathrm{g}) ; 33$, antenna 1, right, $\sigma^{\circ}$ $(\mathrm{g}) ; 34$, detail of flagellum of antenna 1 , right, $\sigma^{\circ}(\mathrm{j}) ; 35$, mandible, left, $९(\mathrm{~g}) ; 36$, maxilla 2, right, $\sigma^{\circ}(\mathrm{h}) ; 37$, mandible, right, $\odot$ (g); 38 , penes on sternite 7 (j); 39 , maxilla 1 , right, $\sigma^{*}(\mathrm{~h})$. 


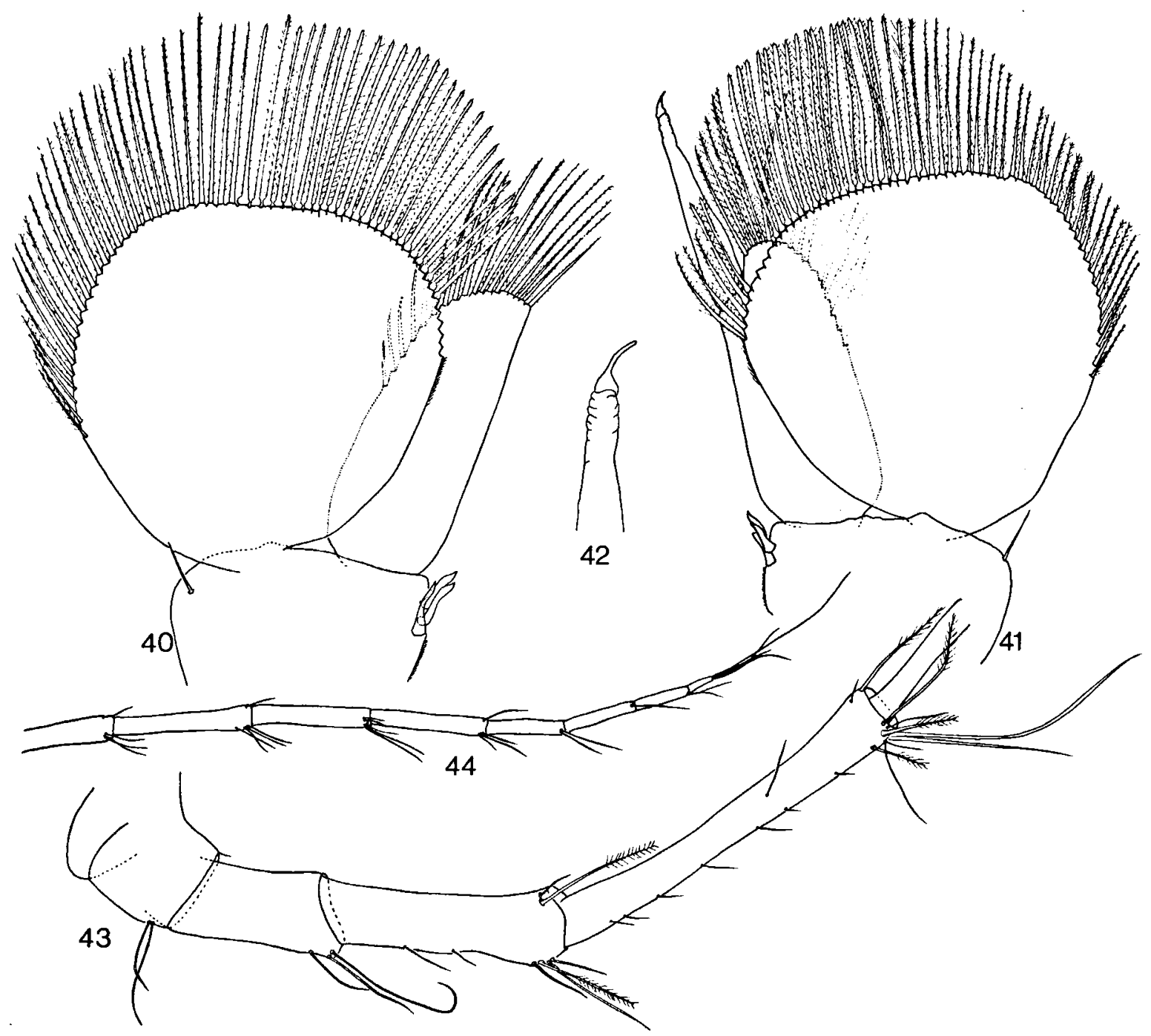

Figs. 40-44. Arubolana imula Botosaneanu \& Stock, 1979, topotypes: 40, pleopod 2, right, $९$ (scale g); 41, pleopod 2, left, $\sigma^{\circ}(\mathrm{g})$; 42, detail of appendix masculina $(\mathrm{j}) ; 43$, peduncle of antenna 2, left, $\sigma^{\circ}(\mathrm{g}) ; 44$, flagellum of antenna 2 , left, $\sigma^{\circ}(\mathrm{g})$.

and 2 simple setae; exopodite with 11 spines ( 2 longer ones have small teeth) and 1 serrate seta (fig. 39).

Maxilla 2: lobe-like, apex armed with 3 longer plumed setae and 2 small simple setae (fig. 36).

Maxillipedal endite with 2 plumose setae, without coupling elements; palp 4-articulated, article 1 squarish, with 1 seta, article 2 the largest with $1+4$ setae, article 3 with $1+3$ setae, article 4 the smallest with 7 setae (figs. 31-32).
Median margin of protopodite of pleopod 1 armed with 3 spines, endopodite slightly smaller than exopodite.

Pleopod 2 male: protopodite armed on median margin with 3 spines, lateral margin with one simple seta; exopodite rather broad on distal end, mediodistal margin with about 26 setae with blunt tip and broader base, remaining setae tapering to the tip; endopodite about the same length as exopodite, setae without blunt tip, appendix masculina implanted subterminally on the median margin, straight 

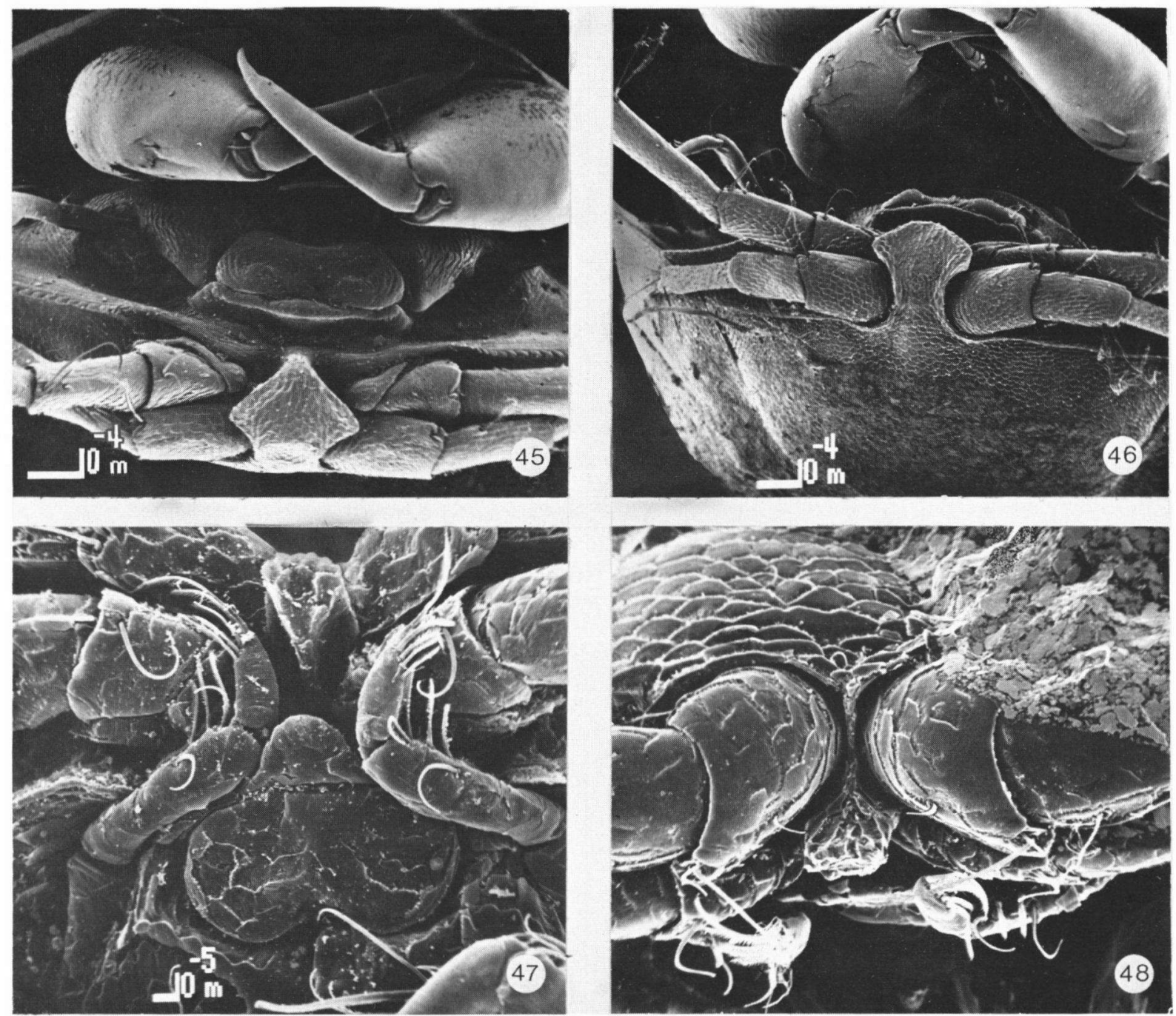

Figs. 45-48. Scanning electron microscopical photographs. 45-46, Arubolana imula Botosaneanu \& Stock, 1979, topotypes: 45, ventral view of clypeal region; 46, head, anterior. 47-48, Arubolana parvioculata $n$. sp.: 47, ventral view of clypeal region; 48 , head, anterior (same magnification as 47 ).

in adult specimens, with a spiniform element on the apex (figs. 41-42).

Pleopod 2 in the female basically the same as in the male, endopodite densely armed with plumose setae (fig. 40).

Pleopod 3: protopodite armed with 3 spines on the median margin and 1 simple lateral seta; mediodistal margin of exopodite with about 30 setae of the blunt-tip type.

Pleopods 4 and 5: protopodite armed with 3 median spines and one lateral seta; exopodite without blunt-tip setae.
Uropodal protopodite wedge-shaped, mediodistally one plumose seta, laterodistally two simple setae; endopodite longer and wider than exopodite, on tip a group of naked setae, plumose setae laterally; exopodite oblong and narrow, armed with naked setae on its apex.

Habitat. - The Mangel Cora Tunnel at Lago Colony on Aruba is still the only known locality of Arubolana imula. The tunnel was tirst described by Wagenaar Hummelinck (1979). During the Amsterdam Expeditions to the West 
Indian Islands, the tunnel was visited a couple of times. During the first visit in May 1978, a single specimen of $A$. imula was found together with large quantities of Metaniphargus longipes Stock, 1977 (hadziid Amphipoda) and Typhlatya sp. (Decapoda, Atyidae). On 24 May and 6 June 1980 the tunnel was visited again. This time a few specimens of Cyathura hummelincki Botosaneanu \& Stock, 1982 (Isopoda, Anthuridea) were also found together with more specimens of the cirolanid.

The substrate on the bottom of the water filling the tunnel consists mainly of very fine silt and the water becomes very quickly muddy during sampling. The largest densities of animals are found in places with pieces of rotting wood. The temperature of the water is approximately $30^{\circ} \mathrm{C}$.

During years the tunnel was used for pumping industrial water and as a result the water became more and more brackish. Since 1980 the tunnel is not used anymore. In 1955 Wagenaar Hummelinck registrated a chloride concentration of $1340 \mathrm{mg} / \mathrm{l}$, while in 1978 and 1980,3600 and $3782 \mathrm{mg} / \mathrm{l}$ were measured, respectively.

More information about this remarkable habitat can be found in Wagenaar Hummelinck (1979) and Botosaneanu \& Stock (1979 and 1982).

Arubolana aruboides (Bowman \& Iliffe, 1983)

Remark. - This species has been described as Bermudalana aruboides. The authors realized that Bermudalana might be synonymous with, or a subgenus of, Arubolana. They decided to describe a new genus, close to Arubolana, on account of differences in pereiopods and pleonites. They concluded: "the differences are usually believed to be of generic value in the Cirolanidae, hence we have proposed a new genus for the Bermuda cirolanid. We realize however, that a plausible case could be made for assigning the latter to Arubolana or for recognizing Bermudalana as a subgenus of Arubolana" (see further Discussion).
Habitat. - This species is only known from anchialine habitats (salinity of the water about that of seawater) in the Church and Wonderland caves on Bermuda. Divers observed the animals swimming several meters above the bottom of the cave lakes; no specimens were ever observed crawling over the substrate. Bowman \& Iliffe (1983) suggest that Arubolana aruboides is a predator capturing its food from open waters.

\section{DISCUSSION}

The genus Arubolana is a clearly recognizable unit within the Cirolanidae owing to the first antenna with only 5 flagellum articles of which the first is 2 to 3 times as long as the remaining articles together, the second antenna with relatively few flagellum articles, the reduced maxilla 2, the slender 4-articulated maxillipedal palp, the prehensile first and second pereiopods, the subterminally implanted appendix masculina, the exopodite of pleopod 5 with few marginal setae, and the presence of five pleon segments.

The three known Arubolana species differ from one another in the following aspects:

- General: $A$. parvioculata is the smallest, maximum length $2.9 \mathrm{~mm}, A$. aruboides has a maximum recorded length of $4.0 \mathrm{~mm}$, the largest is $A$. imula with a maximum length of $6.25 \mathrm{~mm}$; the first two species are slender and slightly more than three times as long as wide, $A$. imula is a more robust species about 2.3 times as long as wide. A. parvioculata possesses small eyes, however, the two other species are totally blind.

- Pleonites: in $A$. imula the fifth pleonite is totally encompassed by the fourth, in $A$. parvioculata this pleonite is only partly encompassed, whereas $A$. aruboides has a free fifth pleonite. The difference between these last two species is, however, small and is possibly evoked by varying degrees of muscle contraction and telescoping of the somites.

- Anteroclypeal region: in $A$. imula the frontal lamina is wide, not abutting posteriorly 
on the clypeus and fused anteriorly with the rostrum; $A$. aruboides and $A$. parvioculata have a triangular clypeus and a freely projecting frontal lamina; only $A$. parvioculata has a freely projecting clypeal apex.

- Third pereiopod: in $A$. imula this is undeniably ambulatory, in the other two species its morphology is intermediate between the second and the fourth pereiopods; in $A$. aruboides this pereiopod seems to be in a more prehensile state (also considering the armature) (Bowman \& Iliffe, 1983, consider it clearly prehensile); however, in $A$. parvioculata it is in a more ambulatory state.

- Pleopods: these are very similar in A. imula and $A$. parvioculata; notable is the very small endopodite of the third pleopod in these two species; $A$. aruboides differs, among others, in having armed endopodites of pleopods 3 and 4. - U ropod: the endopodite is relatively wide in $A$. imula and $A$. parvioculata; in $A$. aruboides it is relatively oblong.

- Telson: this is linguiform in $A$. imula and $A$. aruboides; $A$. parvioculata has a trapezoidal telson, about the same length as width. The posterior margin is concave in $A$. imula and $A$. parvioculata, in $A$. aruboides it is convex.

Some of the above-mentioned morphological differences (such as in the pleonites and pereiopods) between the three Arubolana species are usually considered to be discriminative at generic level within the Cirolanidae. Possibly the three species have to be recognized as representing different subgenera. Nevertheless, with the knowledge we have at the moment it is difficult to identify subgenera in Arubolana.

There are remarkable differences in habitat, behaviour, and probably food between the three Arubolana species. $A$. imula lives in waters (less than $1 \mathrm{~m}$ deep) of a partly artificial tunnel dug in limestone. The species crawls over the bottom and feeds probably on organic detritus or is a scavenger. A. parvioculata lives in sediments in the mouth of an intermittent river near the coast. It is not excluded that this species also lives in the marine interstitial. Finally, $A$. aruboides is a free-swimming species in deep waters of inland anchialine caves, it is probably a predator on planktonic or nektonic organisms. The salinities of the waters in which the Arubolana species were found, range from brackish to marine. In general the members of the genus Arubolana appear to have a large salt tolerance.

As to the position of Arubolana within the family, this genus shows affinity with the marine genus Metacirolana (see diagnosis in Bruce, 1981). This affinity is showed by morphological similarities concerning the moderately developed flagella of the antennae, the anteriorly broad frontal lamina, the slender maxillipedal palp, the pereiopods without flattened articles and with dactyli in which the secondary unguis is minute or absent (the general shape of the pereiopods is similar in Arubolana and Metacirolana), and the medially produced uropodal protopodite. In addition, both $A$. parvioculata, $A$. aruboides and Metacirolana show a freely projecting anterior margin of the frontal lamina and a lateral margin of pleonite 5 which is either partially or not at all encompassed by the epimera of pleonite 4 . Both $A$. parvioculata and Metacirolana have a downward projecting rounded apex of the clypeus. Besides, $A$. aruboides and Metacirolana have in common the setation of the endopodites of pleopods 3 and 4. A. imula has a more Metacirolana-like habitus, but the rostrum, frontal lamina, clypeus and pleonite 5 are totally different.

Although Arubolana in general shows affinity with Metacirolana, this is more strongly expressed in $A$. parvioculata and $A$. aruboides. Metacirolana is a taxon with cosmopolitan distribution, but apparently poorly represented in the Carribean (see Bruce, 1981).

\section{ZOOGEOGRAPHY}

It is most likely that hypogean cirolanid species evolved from marine ancestors. The family is mainly distributed in the seas; epigean continental taxa are almost unknown, and the hypogean representatives show a disjunct distribution pattern. For the West Indian taxa this is shown on map 1. This map also 


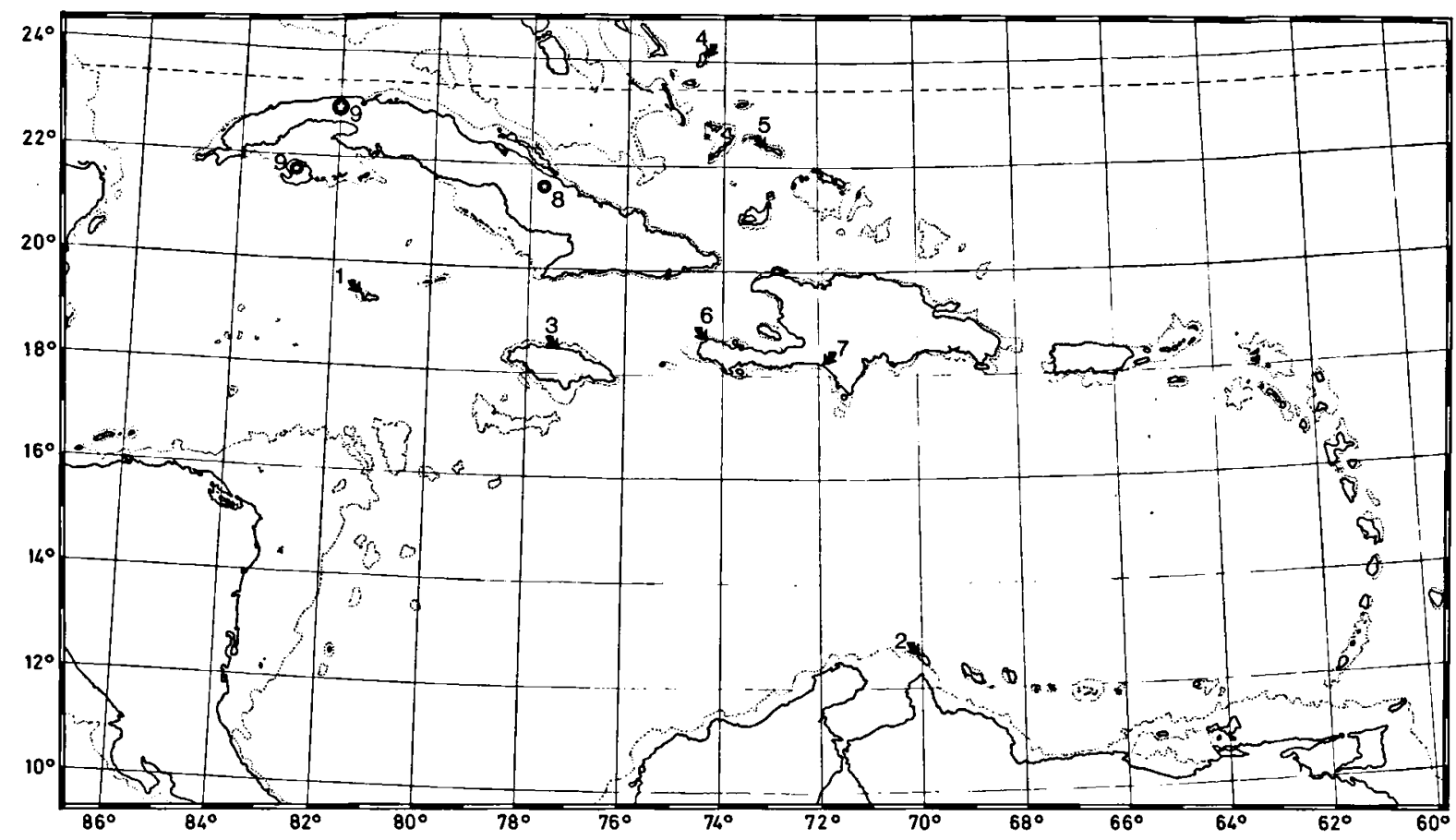

Map 1. Distribution of West Indian hypogean cirolanid taxa: 1, Anopsilana crenata Bowman \& Franz, 1982; 2, Arubolana imula Botosaneanu \& Stock, 1979; 3, Arubolana parvioculata n. sp.; 4, Bahalana geracei Carpenter, 1981; 5, Bahalana cardiopus Notenboom, 1981; 6, Haitilana radicicola Notenboom, 1981; 7, Haitilana acanthura Notenboom, 1981; 8, Haptolana trichostoma Bowman, 1966; 9, Troglocirolana cubensis (Hay, 1903), based on Silva Naboada (1974). Arubolana aruboides (Bowman Iliffe, 1983), from Bermuda, is not indicated on the map because this island is situated out of its frame. Asterisks are used to indicate more than one locality in larger areas. Arrows indicate single localities or more localities in a very small area.

demonstrates that nearly all localities are situated in the neighbourhood of the present sea coasts. Exceptions are the localities of the two Cuban taxa. These are, especially Haptolana trichostoma, more inland cave inhabitants.

For the explanation of this distribution pattern we can assume an active or a passive model. An active process is dispersal from the marine littoral into the groundwater habitats near the coast. A passive model can be regression, i.e. the stranding of marine populations during geotectonic uplifts after the populations adapted to mixohaline or limnic conditions. This model is exemplified by Stock (1976, 1977a, b) for several West Indian stygobiont taxa, for example: Thermosbaenacea, ingolfiellid and hadziid Amphipoda. An evolution corresponding to this regression model for subterranean Cirolanidae is assumed by Botosaneanu \& Stock (1979) for Arubolana imula to have taken place in the late Miocene/Pliocene period and by Notenboom (1981) for the Haitilana species in the Cenozoic period.

Another question is how did marine ancestors colonize the littoral of the oceanic island Bermuda and which mechanism acted in the evolution of Arubolana aruboides from its marine stock. Bermuda consists of a mid-ocean volcanic seamount capped with Pleistocene and Recent, marine and eolian, limestones. The karst was formed during low stands of sea level corresponding to periods of Pleistocene glaciation (Bowman \& Iliffe, 1983). It is likely that in the same periods or more recently, the marine ancestor of $A$. aruboides colonized the anchialine 
cave habitats. This colonization could have happened by dispersal, but also by regression, during the sea-level falls in the Pleistocene.

The habitat in which $A$. parvioculata has been found is clearly intermediate between the marine littoral and the inland groundwaters. The different salinities of the water in which $A$. parvioculata lives is indicative of the euryhalinity of the species. The small size and rather elongate body shape is typical of inhabitants of interstitial biotopes. In river estuaries, such as the locality of $A$. parvioculata, sedimentation is the dominant geological process. All this suggests that it is more likely that this species originated through dispersal from a marine stock. Nevertheless the locality, Discovery Bay, is situated in an area with geotectonically uplifted Plio-Pleistocene terraces, therefore also regression has to be taken into account.

All three Arubolana species appear to have evolved from marine ancestors in relatively recent geological times, late Cenozoic or Pleistocene. It is difficult to conceive a general model in which this evolution could have acted. For Arubolana imula regression is very plausible, but for $A$. aruboides and $A$. parvioculata regression and/or dispersal are both possible.

\section{ACKNOWLEDGEMENTS}

I would like to thank Prof. Dr. J. H. Stock who has given me the opportunity to continue my work on West Indian hypogean cirolanid isopods, and Dr. L. Botosaneanu for useful discussions. Both have read the manuscript of this paper. Mr. N. L. Bruce is thanked for personal advice on Cirolanidae, and Susan Parren-Gardner for reviewing the English text.

The fieldwork has been supported by grants from the Beijerinck Popping Fonds (Amsterdam), the Treub Maatschappij (Utrecht), and the Amsterdamse Universiteits Vereniging (Amsterdam).

\section{REFERENCES}

Botosaneanu, L. \& J. H. Stock, 1979. Arubolana imula n. gen., n. sp., the first hypogean cirolanid isopod crustacean found in the Lesser Antilles. Bijdr. Dierk., 49 (2): 227-233.

- \&- 1982. Les Cyathura stygobies (Isopoda, Anthuridea) et surtout celles des Grandes et des Petites Antilles. Bijdr. Dierk., 52 (1): 13-42.

Bowman, T. E., 1966. Haptolana trichostoma, a new genus and species of troglobitic cirolanid isopod from Cuba. Int. J. Speleol., 2: 105-108, pls. 24-27.

Bowman, T. E. \& R. Franz, 1982. Anopsilana crenata, a new troglobitic cirolanid isopod from Grand Cayman Island, Caribbean sea. Proc. biol. Soc. Wash., 95 (3): 522-529.

BoWman, T. E. \& T. M. Iliffe, 1983. Bermudalana aruboides, a new genus and species of troglobitic Isopoda (Cirolanidae) from marine caves on B srmuda. Proc. biol. Soc. Wash., 96 (2): 291-300.

Broodbakker, N. W. \& D. L. Danielopol, 1982. The chaetotaxy of Cypridacea (Crustacea, Ostracoda) limbs: proposals for a descriptive model. Bijdr. Dierk., 52 (2): 103-120.

Bruce, N. L., 1981. Cirolanidae (Crustacea: Isopoda) of Australia: diagnosis of Cirolana Leach, Metacirolana Nierstrasz, Neocirolana Hale, Anopsilana Paulian \& Deboutteville and three new genera - Natatolana, Politolana and Cartetolana. Aust. J. mar. Freshwat. Res., 32: 945-966.

cirolanid isopods" (Brill, Leiden).

Carpenter, J. H., 1981. Bahalana geracei n. gen., n. sp., a troglobitic marine cirolanid isopod from Lighthouse Cave, San Salvador Island, Bahamas. Bijdr. Dierk., 51 (2): 259-267.

Hummelinck, P. WagenaAr, 1979. De grotten van de Nederlandse Antillen. Caves of the Netherlands Antilles. Uitg. natuurw. Studiekring Suriname, 97 (Natuurhist. Reeks, 1): 1-176.

Monod, Th., 1930. Contribution à l'étude des Cirolanidae. Annls. Sci. nat., (Zool., 10) 13: 129-183.

Notenвoom, J., 1981. Some new hypogean cirolanid isopod crustaceans from Haiti and Mayaguana (Bahamas). Bijdr. Dierk., 51 (2): 313-331.

Racovitza, E.-G., 1912. Cirolanides (première série). Archs. Zool. exp. gén., (5) 10: 203-329, pls. XVXXVIII.

Rıoja, E., 1956. Datos sobre algunos isópodos cavernícolos de la isla de Cuba. An. Inst. Biol. Univ. Mex., 27 (2): 437-462.

Silva Naboada, G., 1974. Sinopsis de la espeleofauna Cubana. Serie espeleologica y carsológica, 43: 43-44 (Academia de Ciencias de Cuba, Instituto de Geografia, Departemento de Espeleologia, La Habana).

Stock, J. H., 1976. A new genus and two new species of the crustacean order Thermosbaenacea from the West Indies. Bijdr. Dierk., 46 (1): 47-70.

- $1977 \mathrm{a}$. The taxonomy and zoogeography of the haziid Amphipoda, with emphasis on the West Indian taxa. Stud. Fauna Curaçao, 55: (177) 1-130.

$-1,1977 \mathrm{~b}$. The zoogeography of the crustacean suborder Ingolfiellidea, with descriptions of new West Indian taxa. Stud. Fauna Curaçao, 55 (178): 131146. 